\title{
THE PROPOSED CABLE COMMUNICATIONS ACT OF 1975: A RECOMMIENDATION FOR COMPREHENSIVE REGULATION
}

In recognition of the increasing importance of the cable television industry, ${ }^{1}$ the Office of Telecommunications Policy (OTP) ${ }^{2}$ has drafted a bill entitled "The Cable Communications Act of 1975." This bill, if enacted by Congress, ${ }^{3}$ will amend the Communications Act of $1934^{4}$ to provide the first coinprehensive statutory regulation of cable TV. ${ }^{5}$

THE FOLIOWING CITATIONS WILL BE USED IN THIS NOTE:

Cabinet Commttee on Cable Communications, Cable: Report to the PresDENT (1974) [hereinafter cited as CCR];

FCC Cable Television Advisory Committee on Federal/State-Local RegulaTORY RELATIONSHIPS (1973) [hereinafter cited as FSLAC];

R. Noli, M. Peck \& J. McGowan, Economic Aspects of Television Regulation (1973) [hereinafter cited as NoLL];

Sloan Commission on Cable Communications, On the Cable: The Television OF ABUNDANCE (1971) [hereinafter cited as SLOAN COMM'N];

"Services" vol., Television Digest, Television Factbook No. 44 (1974-75 ed. 1974) [hereinafter cited as TelBVISION FACTBOOK];

Federal Communications Coının'n, Cable Television Report and Order, printed in 37 Fed. Reg. 3252, 36 F.C.C.2d 141, 24 P \& F Radio Reg. 2d 1501 (1972) [hereinafter cited as Cable Television Report and Order];

Federal Communications Comm'n, Clarification of the Cable Television Rules and Notice of Proposed Rulemaking and Inquiry, printed in 39 Fed. Reg. 14,288, 46 F.C.C. 2d 175, 29 P \& F Radio Reg. 2d 1621 (1974) [hereinafter cited as Clarification];

Memorandum from Henry Goldberg, General Counsel of the OTP, to William V. Skidmore, January 10, 1975, on the subject of the Cable Cornmunications Act of 1975 (responding to comments on the first draft of the Act and explaining revisions) [hereinafter cited as Goldberg Meniorandum];

Proposed Cable Communications Act of 1975, on file at the business office of the Duke Law Journal, Durham, North Carolina [hereinafter cited as Proposed Act].

1. In 1964, there were 1,200 operating cable systems, serving $1,085,000$ subscribers; by 1974, these numbers had grown to 3,158 systeins and $8,700,000$ subscribers. TELEvISION FACTBOOK 71-a.

2. The OTP is currently a branch of the Executive Office of the President. See 47 C.F.R. $\S \S 201.0$ et seq. (1973). See also Exec. Order No. 11,556, 3 C.F.R. 283 (1974).

3. After having been revised from an earlier version in the light of comments received from various government agencies and from industry, the bill is currently awaiting final approval by the Office of Management and Budget.

4. 47 U.S.C. \$\$ 151 et seq. (1970).

5. This area is now extensively regulated by the FCC, and to a lesser extent by state and local governments. See notes 13-26 infra and accoinpanying text. 
It is the purpose of this Note to measure the proposed legislation against the objectives which such a regulatory scheme should serve. First, it will be necessary to give a brief technical explanation of cable TV. The Note will then describe the various types of regulations currently enforced by the FCC and by state and local governments. Next, a summary of the bill will be presented. The final section will evaluate the bill's most significant provisions and make suggestions for improvement.

\section{What is Cable Television? ${ }^{\circ}$}

In contrast to regular $T V$, which is broadcast as a radio signal and received through the viewer's antenna, cable TV more nearly resembles a telephone system. Programming is sent from the origination end, or "head end," of a main trunk cable which serves smaller arteries called "feeders"; individual homes are reached from the feeders by "drops" which enter residences in a manner similar to telephone wires.

There are three methods by which programs may be placed on the cable at the head end. The oldest method in use today is for a cable operator to receive broadcast signals on his own antennas and retransmit them to his subscribers. This method originally was used to improve service to individual viewers in an area of poor broadcast reception; a more recent, and more controversial, use of this method is for a cable operator to construct highly efficient antennas and relay facilities and "inport" the stations normally received in some other area." The second method is called "origination cablecasting," which simply means that a cable operator originates his own programs at the head end in much the saine manner as a local broadcast station which provides original programming. Third, it is possible for cable programs to be originated by a network and transmitted to cable operators, who then would be able to restrict the reception of these programs to their subscribers. $^{8}$

The most inportant characteristic of cable TV, and its greatest advantage im comparison with broadcast television, is the inultiphicity of channels. The possibilities of expanding regular TV are greatly lim-

6. See generally Cable Television Information Center, Cable: An Overview 5-8 (1972).

7. The "importation" of distant signals described here is currently restricted by FCC regulations. See 47 C.F.R. $\$ \$ 76.59-.63$ (1973). See also id. $\S \S 76.91-.159$. See text accompanying notes 66-75 infra.

8. Such "networking" would probably be associated with an "interconnection service" which would permit the direct exchange of programs among the head ends of different cable systems; however, the networking could consist of a simple one-way distribution from the network to the cable systems' head ends with no other interconnection. 
ited by the technical aspects of radio signals. In a given locality, only one broadcast station can use a particular frequency band, ${ }^{9}$ and because of possible interference there generally may not be even two stations on adjacent channels. ${ }^{10}$ Furthermore, the number of channels available in one locality may be limited by the risk of interference resulting froin assigning the same channels to nearby localities. In contrast, a cable system can carry numerous channels and generally use adjacent channels. Therefore, the use of cable requires the preemption of fewer frequency bands than equivalent broadcast programming. Utilized to their fullest extent, cable systems could retransmit all the local broadcast stations, import distant stations, originate local programs, dedicate channels to a wide variety of public uses, ${ }^{11}$ and yet use no more of the limited frequency spectrum than a broadcast system which would provide many fewer services. As the deinand for use of the frequency spectrum continues to increase, ${ }^{12}$ this factor could become extremely important in any challenge which cable TV might eventually make to the supremacy of broadcast TV.

9. As a result, it is technically unworkable to have more than seven channels in the VHF (very high frequency) part of the spectrum (channels 2 through 13). The UHF (ultra high frequency) part of the spectrum (channels 14 through 83) could provide for a greater, though still limited, expansion of broadcast TV, but the development of UHF TV has been hampered by many problems. Many homes with UHF reception lack the proper antennas; UHF stations generally have low power transmitters with a resulting limitation of the signal's range and clarity; UHF radio waves are more nearly line-of-sight than VHF and therefore have a shorter range; and the older UHF continuous tuners are not so conveniently used as the click-stop tuner on VHF channels. See R. Park, Cable TeleVision and UHF Broadcasting 8 (1971).

10. SlonN Comm'N 17. Because of frequency gaps between channels 4 and 5 and between channels 6 and 7 of the VHF system, neither of these pairs consists of adjacent channels, and therefore both members of either pair can be used.

11. Many educational programs could be offered by using cable to provide a citywide closed circuit system. A continuing program of medical education (including cablecasts of surgery and other techniques), further legal training, and programs for local police and fire departments are ouly a few of the possibilities. See generally SLOAN COMM'N 102-10; R. SMTTH, THE WIREd NATION 86-88 (1972). Also, because of the large number of channels available, the marginal cost of channel time should be low enough that cultural programming, which is too costly for broadcast TV, might be economical on cable TV. Broadcast TV, having so few channels, must appeal to mass audiences, whereas cable TV, with its abundance of channels, can afford to devote some channels to smaller audiences and indeed must do so to maximize profits. See Noll 50-53.

12. This demand comes from widely diverse sources, imcluding mobile telephones, mobile-service radios for vehicles such as taxis, and for various intra-corporation uses, in addition to radio and TV broadcasters. See generally SLOAN COMM'N 17, 20-22. Television makes particularly hard demands on the available frequencies. One color TV channel uses as broad a band of the frequency spectrum as $240 \mathrm{FM}$ or $600 \mathrm{AM}$ radio stations. R. Coll \& M. Botein, Cable Television: Tapping the Potential 28 (1972). 


\section{Present Regulation of Cable TV}

The promising medium of cable TV is currently regulated by the FCC, ${ }^{13}$ by a large number of local governments, and by several of the states. State imtervention in this area has been rare and usually limited in scope to the coordination of cable regulation and, in a few cases, to specific measures aimed at corruption and lack of expertise in local governments. ${ }^{14}$ Because of the absence of state preemption in this area, local governments have been able to exercise wide authority over matters not regulated by the FCC. Their inost important power has been the discretion to grant the franchises authorizing cable operators the use of public rights of way. ${ }^{15}$

Regulation by the FCC derives from the fact that cable systems retransmit broadcast signals. ${ }^{18}$ The present $\mathrm{FCC}$ regulations ${ }^{17}$ broadly cover the most important aspects of cable commumications. They prohibit cable operations without FCC approval ${ }^{18}$ and also affect approval at the local level by imposing certain requirements upon cable licensing authorities regarding hicensee selection and franchise agreeinents. ${ }^{19}$ In addition, the regulations place certain restrictions upon the importation of outside signals and require that all locally available stations be retransmitted. ${ }^{20}$ They also protect "exclusivity"; that is, they permit a

13. The FCC's regulatory authority is exercised pursuant to the Communications Act of 1934, 47 U.S.C. $\S \S 151$ et seq. (1970). The leading Supreme Court cases defiming the extent of this authority are United States v. Midwest Video Corp., 406 U.S. 649 (1972) (upholding an FCC requirement that large cable systems must originate programming), and United States v. Southwestern Cable Co., 392 U.S. 157 (1968) (upholding FCC power to regulate cable TV). Most of the cable regulations are included in 47 C.F.R. $\$ \$ 76.1$ et seq. (1973).

14. See generally Barnett, State, Federal, and Local Regulation of Cable Television, 47 NOTRE DAME LAW. 685, 687, 690-708 (1972).

15. See id. at 685-86.

16. The FCC apparently concedes that its present authority would not extend to cable systems which originate all their programming. The present FCC regulations exclude such systems from their eoverage by defining "cable television system" to mclude only systems that retransmit broadcast signals. See 47 C.F.R. $\$ 76.5$ (a) (1973).

17. The main body of these regulations can be found in 47 C.F.R. $\$ \$ 76.1$ et seq. (1973), originally issued with Cable Television Report and Order. For more complete discussions of the FCC regulations, see S. RIvkin, CABLE Television: A Gume To FEDeral Regulations (1973); Comment, Federal and State Regulations of Cable Television: An Analysis of the New FCC Rules, 1971 DuKE L.J. 1151.

18. 47 C.F.R. $\$ 76.11$ (1973).

19. Id. $\$ 76.31$. "Reasonable duration" is the general requirement for the length of a franchise. The FCC has stated that normally "a franchise should not exceed 15 years." Cable Television Report and Order $\Uparrow$ 182. The FCC is considering a minimum length requirement of five to seven years. Clarification IโT 73-74.

20. Signals can be imported to provide programming from all three networks and as many as five independent signals. This latter figure varies with the size of the market served by the cable system and with the number of local mdependent stations. 47 
broadcaster to be the exclusive source of network or syndicated programming. ${ }^{21}$ Further requirements are that cable systems provide three "dedicated" free channels for specified public purposes, ${ }^{22}$ and that cable systems originate cablecasting. ${ }^{23}$ Originated cablecasting is subject to some content regulation. ${ }^{24}$ Finally, the FCC has placed some restrictions on ownership, forbidding cable systems to have any interest either in a TV network or in a TV broadcast station serving the same area as the cable system. ${ }^{25}$ Similar restrictions on telephone company ownership of cable TV systems in the area served by the telephone company are in effect. ${ }^{26}$

Since 1970, there has been considerable activity directed toward the formulation of a comprehensive national policy. At the agency level, the Federal/State-Local Advisory Committee (FSLAC) appointed by the FCC in 1971 has issued a report expressing its view of the ideal allocation of governmental authority in the cable area. ${ }^{27}$ A Cabinet Committee was appointed by the President in the same year, ${ }^{28}$ and its Cabinet Committee Report proposed a fundamental

C.F.R. $\$ \$ 76.59(\mathrm{~b}), .61(\mathrm{~b}),(\mathrm{c}), .63$ (a) (1973). Extremely small communities (those outside broadcast TV market areas) may import without restriction. Id. \& 76.57(b).

21. Id. $\$ \$ 76.91-.159$. For a discussion of the specific exclusivity provisions, see R. Park, The Exclusivity Provisions of the Federal Communications CommisSion's Cable Television Regulations 1-2 (1972).

22. One channel each must be dedicated to public access, local education authorities, and local government. 47 C.F.R. $\$ \$ 76.251$ (a) (4)-(6) (1973).

23. Id. $\S 76.201$. However, this requirement is applicable only to cable systems with at least 3,500 subscribers. In June 1974, it applied to 687 of the 3,190 systems in operation. See Television Factbook 72-a.

24. Cablecasting is subject to the requirement that conflicting views be offered on important public issues, that anyone personally attacked be entitled to respond (except in cases of attack on political candidates by opponents, attacks on foreigners, and attacks that are part of bona fide newscasts), and that any political candidate who is attacked, or whose opponent is endorsed, in an editorial be allowed to respond. 47 C.F.R. $\S$ 76.209 (1973).

25. Id. $\$ 76.501(\mathrm{a})$. This regulation, if interpreted literally, only prohibits cable systems from owning or having an interest in the networks or in broadcast stations serving the same area as the cable system: "No cable television system . . . shall carry the signal of any television broadcast station if such systein directly or indirectly owns, operates, controls, or has an interest in a [network or local broadcaster]." Id. However, it seems to be generally construed to mean the converse-networks and local broadcasters may not own the cable system. See Federal Communications Comm'n, Cable Television Cross-Ownership, 38 Fed. Reg. 2970, 2976, 39 F.C.C.2d 377, 391, 26 P \& F RADIo REG. 2D 739, 753 (1973) (memorandum opinion and order).

26. 47 C.F.R. $\$ \S 63.54-.57,64.601-.602$ (1974).

27. The FSLAC report covered twenty-nine subject areas. See FSLAC 11-28. There was bitter disagreement over the wisdom and constitutionality of the report's conclusion that states and localities should not be allowed to regulate the same aspects of cable TV, a proposal passed by a vote of twelve to seven. Id. at 30 .

28. Members were the Secretaries of Commerce (Peter G. Peterson, who replaced 
scheme of governmental regulation. The culmination of these efforts is the proposed Act drafted by the OTP. The OTP's director and staff were closely involved with the earlier Cabinet Committee, ${ }^{29}$ and the proposed Act generally follows the Committee's recommendations. ${ }^{30}$

\section{The Proposed Act: AN Overview}

Under the OTP bill, a cable systein could not operate without both a license from a state or local licensing authority ${ }^{31}$ and a certificate from the FCC. ${ }^{32}$ The license may be granted only after fair and open proceedings ${ }^{33}$ by an entity laving exclusive authority to regulate cable TV. $^{34}$ The effect of this latter provision is to require that either the state or the local government assnme full power over the nonfederal aspects of cable TV.$^{35}$ Licenses issued by this authority may last froin five to twenty years and nust not be exclusive. ${ }^{36}$ Notable among the specific provisions is a requirement that cable operators inake at least half of their channels available for lease; ${ }^{37}$ the licensing authority itself inay require an even higher proportion. ${ }^{38}$ Once he has received a li-

Maurice Stans), HEW (Elliot L. Richardson), and HUD (George Romney), as well as presidential advisors Herbert Klein, Leonard Garment, and Robert H. Finch. The Director of the OTP, Clay T. Whitehead, served as Chairman of the Committee. CCR 3 n.1.

29. The OTP's Director chaired the Committee, and the OTP staff did the Committee's staff work. CCR 3 n.1.

30. The proposed Act is "intended to impleinent certain of the recommendations of the [Cabinet Committee]." Goldberg Memorandum 1.

31. Proposed Act $\$ 302$.

32. Id. $\S 202$.

33. Id. $\S 303(\mathrm{a})$.

34. Id. $\S 301$.

35. Therefore, the OTP bill basically approves the "Federal Plus One" regulatory scheine adopted by a 12-7 inajority of the FSLAC. See note 134 infra.

36. Proposed Act $\S 303(c)$.

37. This result is compelled by two of the proposed subsections. An operator is required to inake available for lease any channels beyond those necessary to retransmit signals as required by the FCC, to provide a public access cliannel, and to originate programs on two channels. Id. $\$ 303$ (f). Subsection 303 (e) requires that newly constructed systems have enough capacity so that as many channels will be available for lease as are used by the operator for retransmissions or originations. Id. $\S 303(\mathrm{e})$. The effect of both requirements is that half of the channels must be available for lease.

The construction requirement of section 303 (e) by its terms applies only to systems constructed or substantially nodified after the effective date of the Act. However, a similar result is required for existing systems under the FCC rules, which require that all systems have an equivalent cliannel for each channel used for retransmitting broadcast signals, 47 C.F.R. $\$ 76.251$ (a) (2) (1973). This provision is narrower than that of the bill, since the proposed Act will require equivalent channels also for each used by the operator for prograin originations, but the effects will be coinparable.

38. Proposed Act $\$ 303(\mathrm{~g})$. 
cense, a cable operator may obtain the requisite FCC certificate upon compliance with the appropriate rules promulgated by the FCC. ${ }^{39}$

The OTP bill both modifies and adds to the ownership restrictions already imposed by FCC regulations. ${ }^{40}$ The opportunity for telephone companies to own cable systems will continue to be severely limited. ${ }^{41}$ However, it appears that the current restriction against national networks will be relaxed. ${ }^{42}$ Substantial use restrictions are also placed on ownership by newspaper or magazine publishers ${ }^{43}$ and broadcasters. ${ }^{44}$ Similar use restrictions are placed on the owners of multiple systems. ${ }^{45}$

The bill would allow the Commission to set technical standards for cable systems, ${ }^{46}$ as well as pernitting FCC protection of equal employment opportunity ${ }^{47}$ and cable operators' access to rights of way. ${ }^{48}$ Unlike the current regulatory scheme, however, no authority would be allowed to control the content of programs originated on cable TV; in particular, the equal time, fairness, and balance rules are expressly rejected. ${ }^{49}$ Nor would the present "dedicated channels" requirement" be preserved in the bill, which at most would permit a licensing authority to require cable operators to provide free time on one public access channel. ${ }^{51}$ There would be no regulation of the rates charged by operators to channel lessees (at least, not for a ten-year period) or of the rates charged by channel programmers for advertismg and pay-

39. Id. $\$ 203(\mathrm{a})$.

40. See notes 84-102 infra and accompanying text.

41. Proposed Act $\$ 203$ (b)(3). However, telephone companies may install transmission facilities and lease them to the operators. Id.

42. Id. $\$ 204(\mathrm{~d})$. This section provides that networks cannot be prohibited from owning a cable system if their use is limited to the channels needed to carry broadcast stations that are required to be retransmitted, a public access channel, and one channel for program origination by the operator.

43. Id. $\$ 401$ (d). The restrictions are the same as those described in note 42 supra, except that two channels would be allowed for program origination by the operator.

44. Id. $\$ 204$ (d). The restrictions are the sanie as those described in note 42 supra.

45. Id. $\$ 401$ (d). The restrictions are the same as those described in note 42 supra, except that two channels would be allowed for program origination by the operator.

46. Id. $\$ 203(\mathrm{~b})(1)$. This section requires the FCC to set "technical standards necessary to promote the compatibility and interoperability of cable systems, the compatability of the receivers or other terminal equipment connected to such systenus by cable subscribers, and to prevent harmful interference to radio commumications."

47. Id. $\$ 204(\mathrm{c})$.

48. Id. § 204(b).

49. Id. $\$ 401(\mathrm{a})$. Contrarily, the present FCC rules require a presentation of conflicting views on public issues and provide for a right of response. 47 C.F.R. $\$ 76.209$ (1973). See note 24 supra.

50. 47 C.F.R. $\$ \$ 76.251(\mathrm{a})(4)-(6)$ (1973).

51. Proposed Act $\$ 401(\mathrm{~b})$. 
cable service, but the operator's charges to subscribers for regular service may be fixed by the licensing authority. ${ }^{52}$ Operators may be subjected to no taxes or fees other than those common to other businesses, with the exception of "reasonable fees" imposed upon issuance of the license and the FCC certificate. ${ }^{53}$

The bill would allow litigants to sue the operator and the licensing authority in state courts, ${ }^{54}$ and it authorizes the federal district courts to hear those cases without regard to diversity of citizenship or to the amount in controversy. ${ }^{55}$ Individual subscribers would also be protected by certain restrictions on cable-tapping and the disclosure of personally identifiable information. ${ }^{56}$

\section{An Evaluation of the BILI}

\section{The General Approach}

By far the most fundamental issue which should underlie any fornulation of a national cable policy is the extent to which adequate development of cable TV is in the national interest. As the following analysis of the proposed Act will show, almost every major statutory decision must be made in light of how Congress addresses this basic policy question. Certainly the most troublesome aspect of this problein is how to treat broadcasters' claims that cable TV should be restricted in the public interest because of the threat which it poses to broadcast TV. In general, the conclusion of this Note is that the broadcasters' arguinents are weak and that controversies which arise should usually be resolved in favor of the inaximum development of cable TV.

Broadcasters fear that cable systems will reduce the number of viewers for local broadcast stations; indeed, it is not unreasonable for them to suppose that many stations will each liave sinaller audiences when television owners can choose from more channels. Nevertheless, the evidence seems to be that cable TV will probably have little effect on most broadcasters and will certainly not destroy broadcasting altogether. ${ }^{57}$ In fact, some stations may benefit froin the development

52. Id. \& 401(f).

53. Id. $\S 401(\mathrm{c})$.

54. Id. $\S 501$.

55. Id. $\S 502$.

56. Id. $\S 503$. It will be unlawful to intercept cable communications without the consent of the sender; it will also be unlawful for the cable operator or any channel programmer to disclose personally identifiable information about a subscriber, such as what programs he watches, without either the subscriber's consent or a court order. See text accompanying notes $128-31$ infra.

57. See R. Park, Potential Impact of Cable Growth on Television BroadcastING 77 (1970). Such effects will be felt most strongly in smaller towns. Id. at 80. 
of cable TV, particularly those whose audiences will increase as a result of importation by cable systems and UHF stations whose technical disadvantages are cancelled on the cable. ${ }^{58}$ Furthermore, some broadcast stations will undoubtedly be needed to serve areas where cable TV is uneconomical..$^{59}$

Even admitting the possibility that cable TV might destroy or seriousiy injure broadcast interests, one inust still conclude that these contingencies do not justify restricting the development of cable TV. The broadcasters' arguments are based both upon the alleged injustice of allowing their investments to be diminished and the damage which they claim will be done to the public interest. The former argument is especially unimpressive. Every businessman faces the possibility that his product will become obsolete when it faces superior competition; this fact is not generally recognized as a valid reason for imposing artificial restraints upon potential rivals. There is simply no reason for making an exception to this rule for the benefit of TV broadcasters, especially in view of the fact that they paid only a nominal sum for their inost valuable asset: their broadcasting license. ${ }^{60}$

Arguments based upon the public interest have somewhat more substance but cannot withstand close analysis. The contentions are that cable TV would destroy local programming and infringe upon the rights of those who do not subscribe to cable TV. As to the former claim, even ignoring the fact that the current FCC-sponsored local service doctrine ${ }^{61}$ has resulted in little local programming, ${ }^{62}$ one should realize that there will probably be more local programs on cable TV. After all, the abundance of channels will make more programs possible and reduce the marginal cost of programming each channel; one likely

58. The independent UHF stations stand to benefit at least in the short term because, on the cable, the limiting line-of-sight characteristics of UHF will not matter since the cable operator can receive the signal on specialized antennas and amplify it before putting it on the cable; homes with no UHF antenna will be able to receive UHF on the cable; UHF programs can be placed on the cable in such a way that they are tuned in by use of the click-stop VHF channel selector on the TV set, instead of the UHF channel selector, which on many sets is a less convenient tuner. See id. at 7477; Barnett \& Greenberg, Regulating CATV Systems: An Analysis of FCC Policy and an Alternative, 34 LAW \& CoNTEMP. Prob. 562, 576 (1969).

59. Cable TV may be prohibitively expensive in extremely rural areas which have potential audience of very few subscribers for the miles of wire needed to reach them. See Noll 197.

60. See generally id. at 53-54.

61. See Federal Communication Comm'n, Sixth Report and Order, 17 Fed. Reg. 3905, 3913, 41 FCC 148, 171-72 (1952). See generally NoLI 99-120 (discussion of the local service doctrine).

62. See Noll 108-10. 
result is that local programs with less mass appeal would become sufficiently profitable to survive. In evaluating the argument which relies upon the rights of nonsubscribers, one must first concede that such persons do have a legitimate interest in the continued availability of broadcast TV. The fallacy of the claim is due to the fact that, if a substantial number of people fall into this category, enough broadcasters would remain to meet this demand. ${ }^{63}$ If the demand would really be so small that it would not support even a few broadcasters, there is no apparent reason why the nation should forego the full advantages of cable TV in deference to so trifling a demand.

As a starting point, the following analysis of specific provisions will assume that Congress should adopt a firm policy in favor of the maximum development of cable TV. ${ }^{64}$ The arguments which have been advanced against such development are too insubstantial to overcome the public benefits which full exploitation of cable TV as a medium could provide. ${ }^{65}$ Anyone who proposes a specific restriction upon cable 'TV's potential should have the burden of showing that it is clearly in the national interest to forego some of these benefits.

\section{Retransmission of Signals}

It is in the area of cable TV retransmissions of broadcast signals that the conflict between entrenched broadcasting interests and the further development of cable TV is perhaps the strongest. Local broadcasters especially fear the competition of signals "imported" from other areas. Purely from the viewpoint of the broadcasters' self-interest, this fear is not unfounded; the evidence in fact shows that the cable audience increases in proportion to the number of imported stations. ${ }^{66}$ The more appropriate question, however, is whether a particular limitation upon retransmission would serve a public interest apart from the protection of local broadcasters' revenues.

63. According to one estimate, the highest plausible cable penetration is seventy-five percent of the nation's homes. Id. at 160, table 6-3. If this is correct, the development of cable TV would leave twenty-five percent of the population dependent upon broadcast TV. While this is not a small number, the problem would be better met if the FCC allowed the development of regional stations with powerful transmitters and relay cquipment which could reach enough nonsubscribers to be profitable. Even if some public subsidies proved to be necessary, this solution would strike the best balance between the interests of cable subscribers and nonsubscribers. For a brief description of regional stations, see id. at 101 .

64. For recommendations supporting the development of cable TV, see SLOAN CoMm'N 173; CCR 16. See also Proposed Act $\$ 103$ (a) (one purpose of the Act is "to allow the growth and development of cable communications").

65. R. Smith, supra note 11, at 14-21. See notes 9-12 supra and accompanying text.

66. See NOLL 153-55. 
The proposed Act would give the FCC broad powers to regulate the retransmission of broadcast signals by cable operators or channel programmers. ${ }^{67}$ In the exercise of this power, the FCC could require the retransmission of certain stations or programs and forbid the retransmission of others. It is a major weakness of the proposed Act that no distinction is drawn between the power to require and the power to forbid retransmission, since substantially different policy issues are raised by these two types of regulation. Flexible authority in the FCC to require retransmission is desirable as a means of assuring that cable systems at least begin to live up to their potential. To this end, the FCC could use sucli powers to require that a specified minimum service be provided by each cable system. ${ }^{68}$ For example, an appropriate regulation today might require that cable systems carry all three networks and a certain number of independent broadcasters. Because of the changes which will inevitably accompany such a rapidly developing medium, the drafters of the proposed Act chose wisely in giving the FCC flexible powers rather than imposing a statutory standard which might quickly become inappropriate.

On the other hand, the power to limit the retransmission of stations or programs can be exercised only to prevent cable TV from achieving its full potential. The only beneficiaries of such rules would be those local broadcasters who wish to restrain the competition of cable TV. Frequently, the public interest in the greatest variety and highest quality of programming would suffer. For example, a cable operator would not be likely to undergo the effort and expense of importing a distant signal unless he believed that the station or program would find at least a centam number of viewers. ${ }^{69}$ If he miscalculated the probable audience, he would generally discontinue the station or program rather than suffer a loss. A low audience for an imported program would result either from the program's inherent lack of appeal

67. The source of this power is section 204(a), which grants the FCC the authority to "establish by rule or regulation the terms and conditions respecting the retransmission of radio and television broadcast signals by cable system operators or channel programmers ...." Proposed Act \$ 204(a).

68. The present FCC rules do not impose any minimum service standards beyond requiring that all locally available stations be retransmitted. Further minimum service is optional. See note 20 supra and accompanying text. The purpose of the requirement that locally available stations be retransmitted is to prevent a cable operator from dehiberately damaging a particular hroadcast station by carrying only its competitors. The language of section 204(a) is broad enough to allow the retention of this rule. See note 67 supra.

69. The general popularity of imported programming is shown by the correspondence of the size of cable audiences with the number of imported stations. See Noll 153-55. 
or from the competition of superior broadcast programming. There is no apparent reason to disturb the natural operation of this market process in which cable and broadcast TV would compete without artificial advantages or disadvantages. To allow restrictions upon importing would leave the FCC with the power to protect broadcasters against superior cable programming, to the detriment of the viewing public. ${ }^{70}$ Similarly, one inust reject the contention that the FCC should be allowed to prevent cable systems from importing a station whose programming largely duplicates that of a local station. The FCC apparently agrees with this contention, since its exclusivity rules effectively forbid this practice. ${ }^{71}$ However, it seems unlikely that a cable operator would import a signal merely to duplicate programming that was already available locally. He would probably not be motivated to import the signal unless the distant station were in some way superior to the local station and therefore might possibly attract some of the local audience. If a cable system could thus provide better service than local broadcasters offering the same program, the public interest in quality TV would be better served by allowing importation.

For the same reasons, the FCC should be denied the power to retain the "leapfrogging" rules" which it currently imposes in those situations where importation of distant signals is allowed. Under these rules, cable systems are required to import ouly the nearest station offering the desired programming. ${ }^{73}$ The rationale, according to the FCC, is that otherwise most cable systems would import only stations from the largest cities, with a consequent lack of "general participation

70. Perhaps there is a feeling that allowing importation of distant signals would leave some local broadcasters in an unequal contest with big-city stations which can attract the best programming and talent. This would not change the balance of equities, however, since a portion of the public should not be assigned inferior programming merely because of residence location when cable TV is capable of providing even a sinall town the program quality and diversity available in metropolitan areas.

71. See 47 C.F.R. $\$ \$ 76.91-153$ (1973). These rules require that a cable system black out network or syndicated programs and some uon-network services which duplicate those being offered by a local broadcaster. The exact provisions depend upon the size of the TV market iu which the cable system is located. See generally R. PARK, supra note 21 , at 1-2.

72. See 47 C.F.R. $\$ \S 76.59(b), .61(b),(c), .63(a)$ (1973).

73. An imported network station must be the nearest one of the appropriate networks, or the nearest one in the same state as the cable system. As to the independents inported, the first two may come from anywhere, except that if one comes from one of the twenty-five largest markets, then it must come from one of the two closest of those twenty-five largest markets. The third imported signal must be a UHF located within 200 miles, if there is one; if there is no UHF station within 200 miles, the third imported independent station must be either any UHF independent, or a VHF independent located within 200 miles. See id. 
by broadcast television stations in the benefits of cable carriage."74 This reasoning apparently accepts the premise that the public's interest in the best service is less important than the "benefits" which certain broadcasters might have to forego because of an inability to offer a superior product.

It is evident that the FCC has, in general, used its powers over importation to favor broadcasting interests by coinpelling the public to accept programming which might not survive under natural market conditions. In so doing, the Commission has struck the wrong balance. The proposed Act should rectify this by a specific qualification upon the FCC's powers under the retransmission clause, to the effect that no limitations may be imposed on which, or how many, signals may be imported. ${ }^{75}$

\section{Channel Capacity}

The heart of the OTP bill's channel capacity provision is section 303(e) which requires that if a system is built or substantially modified after the effective date of the bill, the system must have "channel capacity of at least one equivalent channel for every channel intended to be used by the cable operator" ${ }^{\prime 7}$ for retransmissions and program originations. ${ }^{77}$ For example, a cable operator who intends to retrans-

74. Cable Television Report and Order If 92.

75. Two other sections of the proposed Act which bave an indirect effect upon importation are sections 204(d) and 401(d). Section 204(d) subjects cable systems to whatever rules the FCC might promulgate concerning common ownership or control of cable systems and TV broadcasters or networks, unless the systems accept severe limitations. The provision would restrict them to the FCC's required broadcast signals, one public access channel, and program originations on one channel. The remaining channels inust be made available for lease to channel programmers unaffiliated with the cable operator. Proposed Act $\$ 204$ (d). The second is section 401(d), which permits licensing authorities or the FCC to prohibit or limit ownership by newspaper or magazine publishers or by persons with ownership interests in other cable systems, unless the systems accept those same severe limitations (except that these systems would be allowed two channels, not just one, for program originations). Id. $\$ 401$ (d).

The purpose of these provisions is to reduce the operator's control of programming. See Goldberg Meinorandum 10 \& 18. Even assuming that this control poses a real danger, there is nevertheless no reason to restrict importation, since imported channels are programmed by their broadcasters, not by the cable operator. The danger that an operator might import only those programs with which he agreed politically is not increased if the operator has interests in other media. There would thus seem to be no reason for not allowing free importation in the circumstances covered by sections 204(d) and 401(d).

76. Proposed Act $\$ 303(\mathrm{e})$.

77. Under the OTP bill, the FCC can prescribe the number of radio and TV broadcast signals that the cable operator must retransmit. Id. $\$ 204$ (a). See notes 67-68 supra and accompanying text. The operator must have capacity to transinit these signals. $I d . \$ 303(\mathrm{~g})(2)$. Also, the cable operator is permitted to have not less than two chan- 
mit three local television stations and to originate programs on two channels must construct a system capable of transmitting ten channels. There are no provisions allowing any agency to force the expansion of systems already in existence when the bill becomes effective. Nor does the bill allow the establishment of minimum channel capacity requirements for existing or future systems. ${ }^{78}$

This resolution of the problem of assuring that sufficient channel capacity is available reflects the philosophy of the OTP bill ${ }^{78}$ that these decisions should be based on market forces and that the operator should estimate the market, ${ }^{80}$ rather than having it defined by government regulation. As a result, the OTP bill is radically different from the current FCC regulations. FCC regulations now require that cable systems in the major TV markets have at least a twenty channel capacity. ${ }^{81}$ The FCC has also promulgated a regulation that would force an operator to add channels if demand exceeded the channels available. ${ }^{82}$

Although the FCC regulations and the OTP bill use different approaehes to insure sufficient capacity, it seems likely that they will achieve approximately the same results. In most major markets, the cable operator probably would want to use at least ten stations for retransmissions and program originations; thus, under the OTP bill he would have to have a system with a twenty channel capacity, the current minimum FCC requirement. As for areas outside of major markets, the FCC has no minimum channel capacity requirements; ${ }^{83}$ thus, the

nels available for program origination. Id. Thus, the cable operator does not have complete discretion to decide how large a system he will build.

78. 1d. $\S 401(e)$. This section forbids the FCC and licensing authorities to "establish or adopt specifications respecting the . . . channel capacity of cable systems ...." The capacity requirements in section 303 (e) are specifically excepted from this provision.

79. See Goldberg Memorandum 2: "More importantly the bill relies upon the most flexible mechanism of all in dealing with cable, that is, the free and competitive marketplace."

80. The operator is discouraged from underestimating the market, because he can be required to lease all the channels except the ones needed for required retransmissions, a public access channel, and two channels for his own originations. Proposed Act $\S$ $303(\mathrm{~g})(2)$. Thus, if he intentionally (or unintentionally) underestimates the market, building only enough channels for himself, he will be forced to give up some of his channels to lessees.

81. 47 C.F.R. $\S 76.251$ (a)(1) (1973). However, the FCC will not allow a licensing authority to require more than twenty channels. Clarification $\mathbb{1} 16$.

82. 47 C.F.R. $\& 76.251$ (a)(8) (1973). However, one commentator has suggested that the cable operator could probably avoid actually expanding the system for a number of years. See S. RIVkin, supra note 17, at 59-60.

83. Cf. 47 C.F.R. $\$ 76.251$ (a)(1) (1973) (channel capacity requirements limited to major markets). 
OTP bill might actually force an increase in the capacity of systems built in those areas.

\section{Restrictions on Ownership of Cable Systems}

The proposed Act places some conditional restrictions on the ownership of cable systems by those organizations which are already disseminating information to the public or which might want to impede the growth of cable TV because it would provide potential competition. These groups, the approval of whose ownership is conditioned upon how they use the system, include newspaper and magazine companies, ${ }^{84}$ owners of TV networks or broadcast stations, ${ }^{85}$ and owners of multiple systems. ${ }^{86}$ Ownership by any of these groups will be approved if the cable operator limits his use to providing only the minimum service of retransmitting required stations, a public access channel, and one $^{87}$ or two ${ }^{88}$ channels of programs originated by the operator. To inake sure that independent programmers are not foreclosed from the market, all channels not used in providing this minimun service are to be available for lease. While the free competition an ${ }^{89}$ of these conditions is laudable, it is possible that independent programmers will not want to use all of the excess channels. Thus, the public would be deprived of additional programming because of the restrictions on these particular types of owners. At a minimum these operators should be given the option to import more signals and preferably to offer automated programming, at least on inore than two channels. ${ }^{90}$

84. Proposed Act $\S 401$ (d). This authorization is actually phrased as a limitation upon any governmental agency or state from prohibiting ownership if these conditions are met.

85. Id. $\S 204(d)$. This restriction applies only to those cable systems located in the areas served by these stations or networks.

86. Id. $\S 401$ (d).

87. Broadcast stations and networks are limited to only one channel for their program originations. Id. $\S 204(d)$.

88. The allowable activity of owners of multiple systems and publishers of newspapers and magazines is limited to that specified in section $303(\mathrm{~g})(2)$ of the proposed Act. See id. $\$ 401(\mathrm{~d})$. Section $303(\mathrm{~g})(2)$ says that the cable operator "shall be permitted to have no less than two channels available for program originations."

89. See Goldberg Memorandum 2.

90. The problem of the operator freezing out the independent should be minimized because section 303(i) provides that the operator desiring to program channels must do so through a separate corporation. These affiliated companies are to be given no better terins than the independent programmers. Proposed Act $\$ 303$ (i). An operator desiring to offer automated programming should be allowed to do so on channels in addition to the two channels that he is allowed for originations so long as he has channels available for lease. Such programming can include news, stock market and sports tickers, message wheels, music, advertising, or time and weather (this last type was offered on more than half the cable systems operational in June, 1974, see Television Factboor 71-a). Programming of this type would not pose a threat to diversity of local programming. 
Another restriction on ownership is aimed at any potential cable system operator "who either directly or indirectly owns or controls access to interconnection facilities serving cable systems, and also supphes programming to channel programiners."91 Such an operator will be licensed only if he promises that he will not provide both interconnection services and programming for the particular cable system which he seeks to operate. ${ }^{92}$ This provision prevents the program provider, the supplier of interconnection services, and the cable operator from being combimed in one corporate entity. Its primary purpose is to protect a channel programmer who wants to lease channels in several different systems in order to form his own network from being forced by a corporation performing all three functions to use only its programs on its systems. ${ }^{93}$ Under this provision, a national network could not acquire a cable systein and then use its program origination cliannel ${ }^{94}$ to distribute its network prograins locally. Although this provision allows networks to participate in the developinent of cable systems and thus relaxes the current regulations, ${ }^{95}$ it has sufficient safeguards to prevent the national networks from abusing their strong economic positions.

Finally, the proposed Act generally prohibits telephone coinpanies from owning cable systems in the areas where they provide phone services. ${ }^{96}$ The purpose of this restriction is to avoid the inevitable doinination of the industry by the telephone companies. Because telephone companies already have in place extensive transmission systems which can readily be modified to include a cable system, their incremental cost of establishing cable systems would be minimal. There is no compelling reason to "give" the developinent of the cable industry to the telephone coinpanies, and the teleplione industry might even have positive reasons for retarding the cable industry. ${ }^{97}$ However, the proposed Act does allow telephone coinpanies to provide "transmission

An operator who does not originate "live" programs should be allowed to offer automated programming without being required to incorporate a programming affiliate. This suggestion would expand a recommendation of the Cabinet Committee that cable system owners be allowed to control programming if they offer no more than local signals plus one or two channels of automated programming. CCR 29 n.1.

91. Proposed Act $\$ 303(d)$. See note 8 supra.

92. Id.

93. The possibility of an independent operator being squeezed out is suggested in CCR 31 .

94. Proposed Act $\S 204$ (d) allows a network-owned cable system to use one channel for program origination.

95. 47 C.F.R. $\$ 76.501$ (1973). See note 25 supra.

96. Proposed Act $\$ 203$ (b) (3).

97. Cable systems might eventually provide telephone service on one channel. $R$. SMith, The WIREd Nation 65 (1972). 
facilities used to distribute or disseminate electromagnetic signals from the primary control center of a cable system to cable subscribers."

Control of the cable industry by the telephone companies is already the subject of FCC regulations. ${ }^{99}$ The regulations are similar to the proposed Act, and the proposed Act seems to recognize their existence because section 203(b) authorizes the FCC "to adopt or continue in force"100 rules and regulations relating to the participation of telephone companies. The existing regulations are probably consistent with the proposed Act. For example, it would appear that the FCC could continue to waive the prohibition ${ }^{101}$ because the language of the bill is not a positive exclusion, but rather says that the FCC shall adopt rules that "limit" telephone company ownership of cable systems. ${ }^{102}$

\section{Access to the Cable}

The access provisions of the OTP bill deal with the problems of giving independent programmers an opportunity to use cable and of providing a "public access" channel. To help the independent programmers, the bill mandates ${ }^{103}$ that operators with capacity in excess of a minimum ${ }^{104}$ must be required to inake that excess capacity available to channel programmers. ${ }^{105}$ The programmers to whom these channels are nade available may or nay not be affiliated with the operator; the purpose seems to be to prevent an operator from building a system and then using it only marginally. The licensing authorities are

98. Proposed Act $\S 203$ (b)(3). The effect of this provision is to authorize telephone companies to build and lease back cable transmission facilities.

99. See 47 C.F.R. $\$ \$ 63.54-.57,64.601-.602$ (1974). The power of the FCC to impose these regulations under section 2(a) of the Communications Act of 1934, 47 U.S.C. $\S 152$ (a) (1970), was upheld in General Tel. Co. v. United States, 449 F.2d 846 (5th Cir. 1971).

100. Proposed Act $\$ 203$ (b) (emphasis added).

101. See 47 C.F.R. $\$ \S 63.55,64.602$ (1974). A waiver is given in those situations where "CATV service demonstrably could not exist except through a CATV system related to or affiliated with the local telephone common carrier . . ." Id. $\$ 63.55$.

102. Proposed Act $\$ 203(b)(3)$.

103. Id. \& $303(\mathrm{f})$.

104. The minimum, set by a cross-reference to section $303(\mathrm{~g})(2)$, is enough channels that the operator may program two himself, retransmit all broadcast stations required by the FCC, and provide a public access channel. In the case of systems involved in cross-ownership situations, this minimum is also the maximum the operator may provide -he may not use the excess even if no other programmer wants it-and in some cases the minimum is even reduced by limiting the operator to one origination channel. See notes 42-45, 84-90 supra and accompanying text.

105. Proposed Act $\$ 303(\mathrm{~g})$. This section would prevent a cable operator from making his two origination channels the only origination channels in the system and would frustrate any effort by a broadcaster to prevent full utilization of cable TV. 
directed to establish a mechanism whereby the operator is required to make these channels available to unaffiliated programmers as demand from independent programmers for leased channels imcreases. ${ }^{106}$ Apparently, the intent of this second provison is to allow most cable operators ${ }^{107}$ to program the full capacity of their systems. Then, as demand develops from independent programmers, the cable operator would have to give up some of his channels or build more channels in order to meet unfulfilled demand. ${ }^{108}$ The cable operator can be reduced to the poimt where lie has channels available only for required retransmission, two channels for program origimation, and one channel for public access. ${ }^{100}$ This provision may discourage operators from spending money to program more than two channels or to import broadcast stations that are not required. However, the operator could protect his imvestment in building up audiences for the programs on these additional channels by enlarging the capacity of his system, and it is in the public interest to encourage him to make channels available. The bill should specifically require that the operator be given a grace period, perhaps six months, after unfulfilled demand reaches the critical point before he is required to surrender a channel on which he has programming in order that lie may have time to install new capacity if he chooses. ${ }^{110}$ The effeot of this access provision would be to

106. Id. $\$ 303(\mathrm{~g})(1)$.

107. Not all operators will be permitted to use any more than the minimum from the beginning because of the cross-ownership restrictions. See notes $42-45,84-90$ supra and accompanying text.

108. This interpretation of section $303(\mathrm{~g})$ is presented in the Goldberg Memorandum 14. The section actually says that the licensing authority shall "require that channel capacity available for lease to channel programmers having no ownership affiliation with the cable operator be increased in proportion to the total channel capacity of the system . . . Un Unfortunately, the language used for this section seems to be an obscure and indirect treatment of the important question of when the cable operator must give up to his potential competitors channels that he is using. Clarity is particularly needed at this point because the licensing authority must devise a formula at the time that the license is granted, and this obscure reference to proportion gives inadequate guidance since it will be difficult, if not impossible, to devise such a proportion without knowing how many channels will be needed. This provision could be clarified by requiring simply an increase, with no reference to proportion. That way, the license could simply require that the operator supply the channels for leasing (at least until all were in use and he and his affiliates were using only the minimum provided by section $303(\mathrm{~g})(2)$ ) whenever demand justified leasing a new cliannel. This demand could be computed on the basis of the extent of usage of channels, as in 47 C.F.R. $\$ 76.251$ (a)(8) (1973), or on the basis of firm offers to lease that were declined for lack of an available channel.

109. Proposed Act $\$ 303(\mathrm{~g})(2)$.

110. The bill should also allow the operator some channels to retransmit more broadcast stations than are required, so that he may provide at least some minimum service such as all three networks plus an independent.

Furthermore, the bill should provide that the operator must be allowed at least two 
deprive the FCC of the power to enforce its current regulations that a cable operator must make available a channel to a programmer when his system is loaded to capacity. ${ }^{111}$ This problem would be handled under the bill by the local licensing authority.

The second provision concerning access to channels is a prohibition of any requirements that the cable operator dedicate channels to particular uses, except that a licensing authority may require that one channel be inade available without charge to all comers for any nonbusiness presentations. ${ }^{112}$ This will be a significant change from the current FCC rules, which require such a "public access" channel ${ }^{113}$ and also require one channel to be dedicated to local government use and another dedicated to use by the local education authorities, ${ }^{114}$ both without any charge. ${ }^{115}$

The general prohibition of mandatory dedicated channels is a sound provision, for it will frustrate any attempt to force cable operators to subsidize local government and education. If the governmental and educational services do benefit from use of a channel, as indeed they probably would, ${ }^{116}$ then the cost should be borne by the entire community, not just by the cable system or its subscribers and channel lessees whose costs would be influenced by these demands on the system. ${ }^{117}$ The government and education authorities should bid in the market for channels.

The public access channel, where it is required, will force the operator to provide a service to benefit the community. However, two

channels for automated programming, as well as two for nonautomatic origination: the sorts of services that can be offered by automatic programming may not be offered by any programmer except the operator, since inserting advertising may add prohibitively to the expense of such programming. See note 90 supra.

111. 47 C.F.R. $\& 76.251$ (a) (8) (1973).

112. Proposed Act $\$ 401(\mathrm{~b})$.

113. 47 C.F.R. $\& 76.251$ (a) (4) (1973).

114. Id. $\$ 76.251(\mathrm{a})(5),(6)$.

115. Cable Television Report and Order fiT 123-24. The requirement that there be no charge for these two channels is regarded as experimental by the FCC. Id.

116. The uses for such channels are myriad. For instance, governments can use their channels as closed circuit systems for training police and firemen, with such features as live cablecasts of fires to permit remote supervision (a closed channel, not available to the public, might be appropriate for such programs) and for providing employment information to the public. School systems can use their channels for conventional TV classes, for special lectures by experts videotaped at the expert's convenience, or for continuing education programs.

117. While some programs would directly benefit only subscribers (such as continuing education), any uses for internal government or education affairs-training, school programs-would benefit the entire community, and in cases where only subscribers benefit directly it is to be anticipated that the commurity as a whole will benefit indirectly. 
elements distinguish this from the forbidden government and education channels. First, short programs by private groups, for nonbusiness purposes, might not be possible unless there is a channel set aside for them. Second, the cost to the operator of providing this channel will be merely the loss of potential channel lease revenue from one channel, whereas under the FCC rules the operator must give up three channels. It is still a burden, of course, and still imvolves making the system pay for something, out of the pockets of its shareholders or its subscribers and channel lessees, that is thought to benefit the whole community. However, this may be the only feasible way to provide such a channel, and it will cost the systein little since it merely uses one channel that can be taken into account in planning the system; thus, this requirement may be legitimately imposed as a cost of doing business.

\section{Regulation of Program Content}

One of the most heartening aspects of the proposed Aot is the broad guarantee in section 401 of the cablecaster's right to freedom of expression:

No executive agency of the United States . . . and no State or political subdivision or agency thereof ... shall:

(a) require or prohibit program originations by a cable operator or channel programmer, or impose upon such operator or programmer any restrictions or obligations affecting the content of such program originations, including rights of response by any person, opportunities for appearances by candidates for public office, or requirements for balance and objectivity . . . . 118

The remainder of the provision makes it clear that the section will not affect civil or criminal liability for defanation, obscenity, incitement, invasion of privacy, false advertising, "or other similar laws."119 This qualification might seein umrecessary, but one desirable result of it would be to reinforce the point that the first amendment guarantees are intended to be very broad since the qualification suggests that the guarantees cover everything not excepted. Its presence will help refute any future suggestions that other, unexpressed exceptions were to be implied froin the provision. Section 401(a), if enacted, would be a clear and welcome departure from the current FCC rules, which wood-

118. Proposed Act $\$ 401$.

119. Id. The provision also states the common-sense doctrine that cable system operators should not be held liable for offenses committed on programs originated by unaffiliated programmers. A contrary provision would attempt to make the operator a guarantor of program content over which he would generally exercise no control. 
enly apply the right-of-reply and other doctrines to cable as well as broadcast TV. ${ }^{120}$ The proposed Act would recognize that cable TV is not bound by the same physical restraints that apply to broadcast TV $^{121}$ and that therefore the application of these doctrines to cable cannot be predicated upon a scarcity of channels. ${ }^{122}$ Nevertheless, it might be objected that the likelihood of a cable operator's having a local monopoly of cable ${ }^{123}$ justifies content controls. ${ }^{124}$ However, the trend toward newspaper monopolies or virtual monopolies in the large cities has not been accepted as a justification for constricting newspapers' first amendment freedoms. ${ }^{125}$ Furthermore, if the bill is enacted in its present form, there will be provisions which assure a multiplicity of views on an individual cable system; cable operators will be required to make at least half of their channels available for lease, ${ }^{126}$ and they will probably be required to retransmit all locally available broadcast stations. ${ }^{127}$ The conclusion, therefore, must be that in replacing the present FCC dootrines with a clear first amendment guarantee, the drafters have recommended the proper approach.

\section{Protection of Privacy}

An important safeguard for the individual subscriber is provided in section 503, which contains a general prohibition of cabletapping

120. 47 C.F.R. $\$ 76.209$ (1973). See note 24 supra. On fairness in broadcasting, see 47 U.S.C. $\$ 315(a)$ (1970) (reference to broadcasters having an "obligation . . . to operate in the public interest and to afford reasonable opportunity for the discussion of conflicting views on issues of public importance"), and Federal Communications Comm'n, Applicability of the Fairness Doctrine in the Handling of Controversial Issues of Public Importance, 29 Fed. Reg. 10,416, 40 F.C.C. 598, 2 P \& F Radio Reg. 2d 1901 (1964) (public notice).

121. See note 9 supra.

122. Scarcity is oue main element permitting the fairness requirenent in broadcasting. Red Lion Broadcasting Co. v. FCC, 395 U.S. 367 (1969), upheld the faimess doctrine requirenent partly on the ground that "the First Amendment confers . . . no right to an unconditional monopoly of a scarce resource which the Government has demied others the right to use," id. at 391, and the Court stated that "[t] $]$ here is no sanctuary in the First Amendment for unlimited private censorship operating in a medium not open to all," id. at 392. See Note, Cable Television and the First Amendment, 71 Colum. L. ReV. 1008, 1017-18 (1971).

123. Cable has been called "a technical or natural monopoly at the local level," largely because it would be uneconomical to operate a second cable system in an area already served by one. R. Posner, Cable Television: The Problem of local MONOPOLX 1 (1970).

124. The FCC has apparently suggested this approach. See Goldberg Memorandum 16. This inay be interpreted, however, as referring only to channels programmed by the operator.

125. Miami Herald Publishing Co. v. Tornillo, 418 U.S. 241, 249-50, 254-55 (1974).

126. See notes 103-10 supra and accompanying text.

127. See notes 20,67-68 supra and accompanying text. 
and of the disclosure by cable operators or channel programmers of personally identifiable information about a subscriber or his viewing without his consent. ${ }^{128}$ While this broad protection is desirable, three omissions seriously weaken its value. First, the bill speaks only in terms of disclosure and does not forbid the unauthorized collection and storage of information, despite the fact that the latter would also be a serious abuse if, for example, a cable operator were to collect data on individual subscribers' preferences in political or "adult" programming. The best approach would be to provide for a blanket prohibition of disclosure, collection, and storage of information, with specified exemptions to serve legitimate purposes. For example, it would be reasonable to exempt inforination collected for billing, for audience surveys, for profitability research by the operator, and for technical quality control. ${ }^{129}$ A second weakness of the privacy section is that its protections would not extend to governmental action. ${ }^{130}$ The federal wiretapping statute does not apply to cable systems, ${ }^{131}$ and some express provisions

\section{Proposed Act $\S 503$ :}

In order to protect the privacy and security of cable communications, no person shall intercept or receive program originations or other communications provided by means of a cable system unless authorized by the cable operator, the program originator or other sender of the communication; and no cable operator, or channel programmer, shall disclose personally identifiable information with respect to a cable subscriber or the programming or other communications service provided to or received by a subscriber by means of the cable system except with the consent of the subscriber, or except pursuant to a court order authorizing such disclosure. If a court shall order disclosure, the cable subscriber shall be notified of such order by the cable operator or other person to whom such order may be directed, within a reasonable time before the disclosure is to be made.

Another aspect of privacy is protected in the proposed Act by the requirements that subscribers be informed of the nature of programs before reception of them, and that devices be provided to enable each subscriber to lock out programming he does not wish to receive. Id. $\$ 203$ (b) (2).

129. It might also be desirable to provide that the FCC or licensing authorities have the power to promulgate rules concerning how long information of specified types may be retained. The periods would vary with the length of time reasonably necessary to utilize the information in the authorized manner. For example, information concerning viewer habits is no longer appropriately retained in individual form for any period of time after being synthesized, and in such cases only a very short time period would be allowed.

130. The prohibitions of section 503 apply only to persons, see note 128 supra, and governments are not "persons" within the contemplation of the Act, see note 146 infra.

131. See 18 U.S.C. $\$ 2511(1)$ (a) (1970). This statute makes it a crime to intercept "any wire or oral communication." However, it does not apply to cable TV because the communication has to be via common carrier, id. \$ 2510(1)-cable TV operators are not considered to be common carriers-and the prohibition on interception of the message applies only to "aural acquisition," $i d$. $\$ 2510(4)$. Further, another wiretap statute, 47 U.S.C. $\$ 605$ (1970), relating to interception of wire or radio communication, also fails to provide any protection because the potentially relevant provisions are linited to radio communications. 
applicable to government conduct would be a significant protection for the public. A final weakness is the absence of appropriate sanctions; a provision making willful noncompliance with this section a misdemeanor and allowing for punitive damages would encourage the observance of safeguards which are clearly important to the subscriber.

\section{Allocation of Nonfederal Regulatory Authority}

Under the OTP bill, states would be required to vest exclusive authority in one entity to regulate licensing and the other nonfederal aspects of cable TV in a particular area. ${ }^{132}$ Therefore, once a county or municipal body ${ }^{133}$ was given powers over local cable TV, state regu-

132. The basic operative provision is section 301 :

A cable licensing authority shall have exclusive authority under state law to execute and enforce the provisions of section 303 [the licensing section] and adopt all other rules, regulations, and procedures respecting those activities characteristic of cable system construction and operation as are consistent with the provisions of this Act, and are not exclusively reserved to the Commission by Title II, or forbidden to an executive agency of the United States, a State, or any agency thereof by Title IV of this Act. Proposed Act $\$ 301$.

It should be noted that the exclusive authority would extend only to matters which are characteristic of cable systems. Presumably, other entities could regulate such matters as insurance requirements or safety standards. See Goldberg Memorandum 11.

The Act also contains a broad grant of lawmaking and rulemaking power:

A state, or any political subdivision or agency, board, commission or authority thereof, may adopt or continue in force any law, rule, regulation, order, or standard affecting cable systems, provided, that such law, rule, regulation or order or standard is consistent with the exclusive grants of authority under Title II and Title $\mathrm{WI}$ of this Act, is not forbidden to any governmental authority under Title IV of this Act, and does not otherwise create an undue burden on the interstate commerce in cable communications. Proposed Act $\$ 104(\mathrm{c})$.

Since section $104(\mathrm{c})$ is expressly made subject to the exclusive-authority rule of section 301, the combined effect of the two sections is to give licensing authorities exclusive lawmaking and rulemaking powers over matters characteristic of cable systems.

A state legislature, having designated cities (or a state agency) as licensing authorities, would not be permitted to enact laws regulating cable TV because that would violate the requirement for exclusive authority. This is not explicit in the proposed Act, but it is implicit. It is doubtful that the omission of the word "law" from section 301 was intended to allow state legislatures to provide statutory regulation of the local imcidents of cable TV while local licensing authorities exercised rulemahing powers over the same regulatory aspects of cable TV. Such an interpretation would nullify the exclusiveauthority provisions, since the legislatures could pass even the most minor regulation as a formal statute or "law," thus overruling local regulations at will. It is probable, however, that the section 301 requirement that exclusivity arise "under state law" would give legislatures at least implied authority to change their minds on where to vest these exclusive powers; a legislature would not be irrevocably committed to its initial choice.

It should also be noted that under the proposed Act a state could delegate exclusive authority to particular entities, such as specified cities, in their respective jurisdictions while retaining exclusive powers over the rest of the state. This scheme would likewise be generally consistent with the views of the FSLAC majority's "Federal Plus One" doctrine. See FSLAC 47-48. See note 134 infra.

133. Section 105(f) of the proposed Act defines a "cable licensing authority" as "any state, county, municipality, or any political subdivision thereof, or any agency, commis- 
lation in that locality would have to cease. In thus endorsing the "Federal Plus One" position of the FSLAC report, ${ }^{134}$ the bill would impose an unnecessary rigidity upon the regulatory structure and would be an unwarranted intrusion upon the states' prerogative to manage their internal affairs. The states should be left free to experiment with different approaches under which states and localities cooperate in regulating cable. For example, it might be found best for local hicensing authorities to control the day-to-day operations of cable, subject to general standards promulgated by the state; such a scheme would be forbidden by the proposed Act. ${ }^{135}$ The evil at which these provisions are aimed is presumably the problem of duplicative regulation. ${ }^{136}$ However, any duplication serious enough to justify sucli restrictions could be dealt with under another provision of the present bill, which invalidates nonfederal regulation that unduly burdens the interstate commerce in cable communications. ${ }^{137}$ Problems of duplication which would be too trivial to constitute sucli a burden are not of sufficient magnitude to warrant the restrictive exclusive-authority provisions. The best approach would be to eliminate the restrictions altogether and

sion, board, or authority thereof, that is empowered by law to authorize by license, franchise, permit or other instrument of authority, the construction and operation of a cable system within the jurisdiction of such agency."

134. As a remedy for possible duplicative regulatiou at the local level, a twelve member majority of the FSLAC recommended that the FCC should totally preempt regulation of cable, but not occupy certain areas so long as states enact laws providing that only one level of state or local government will regulate those areas. FSLAC 46-47. Thus, a cable operator could not be regulated by both a state and a municipal licensing authority. This approach is known as "Federal Plus One." In contrast, the mimority suggested that this restrictive approach is unnecessary, that three-tier (FCC-state-local) regulation is not inevitably duplicative and dilatory, and that the FCC could not constitutionally enforce this provision even if Congress granted the FCC this authority. FSLAC 83-84. See generally id. at 86-105. The constitutional problem derives from the fact that, since local governments are creatures of the states, the powers given to them must derive from the states and not be subjected to congressional allocation. See FSLAC 97-101; cf. Brown v. Gerdes, 321 U.S. 178, 188 (1944) (Frankfurter, J., concurring) (Congress cannot extend state courts' jurisdiction in manner contrary to state law).

135. Any attempt by the state to assert supervisory or other general powers over local licensing authorities would constitute "rules, regulations, and procedures" in contravention of the exclusive-authority requirement of section 301 .

The Cabinet Committee did not recommend any such exclusionary scheme, and in fact suggested that "[s]tates could provide overall guidance and assistance to local authorities in their franchising activities" and specifically mentioned that "[i]f ultimately required, states could also oversee the reasonableness of customer connection charges ...." In short, even if localities are the licensing authorities, states slould have a role. $\mathrm{CCR} 42$.

136. See FSLAC 39-42. See generally id., Pt. II, at 31-54.

137. See Proposed Act $\$ 104(\mathrm{c})$, quoted in note 132 supra. 
thereby grant the states sufficient flexibility to adjust the regulatory pattern as experience might require.

\section{Regulation of Subscriber Charges and Franchise Fees}

The OTP bill contains two provisions relating to the financial aspects of cablecasting. One of these provisions implements OTP's philosophy that cablecasting should be subject to competitive market forces, ${ }^{138}$ it prohibits the government from directly regulating rates charged advertisers and from regulating the "rates charged channel programmers by cable operators for the use of channels or time on such channels for a period of ten years after the effective date of this Act . . .."139 However, to protect individual consumers whose bargaining power is much weaker than that of channel programmers, the OTP bill does allow the licensing authority to fix or regulate the rates that the cable operator charges subscribers for imstallation, maintenance, and regular service. ${ }^{\mathbf{1 4 0}}$ Since cable TV is still in its infancy, the policy adopted by the OTP seems to be an appropriate one. More government regulation of rates might preclude the possibility of earning attractive profits and thus retard the investment of capital necessary for a rapid development of the cable industry. ${ }^{141}$

The second financial provision allows the FCC and the licensing authority to charge an operator a reasonable franchise fee. ${ }^{142}$ This sec-

138. Goldberg Memorandum 2.

139. Proposed Act $\S 401(\mathrm{f})$. The prices could nevertheless be indirectly regulated by means of an antitrust suit brought by the government or by private persons.

140. Id.

141. See id. $\S 103(d)$. One purpose of the proposed Act is to assure that cable TV is "allowed to compete in the marketplace with other communications media." Id. See also Goldberg Memorandum 19.

142. Proposed Act $\$ 401(\mathrm{c})$. The current practice of the FCC is to charge a licensing fee of thirty cents per subscriber per year. 47 C.F.R. $\$ 1.1116(b)$ (1973). This rule is intended, according to $i d$. $\$ 1.1101$, to implement the Independent Offices Appropriation Act of 1952, 31 U.S.C. $\$ 483 a$ (1970). The FCC rule was challenged in National Cable Television Ass'n, Inc. v. United States, 415 U.S. 336 (1974), which held that the fee was permissible only if based upon the "value to the recipient" of the FCC services, id. at 342-43. In other words, Congress gave the FCC authority to levy a fee but did not delegate its taxing power to the FCC. The case was remanded for the FCC to take further proceedings. Id. at 344.

Under the present regulations, the local hicensing authority is permitted to charge the operator a reasonable fee "e.g., in the range of 3-5 percent of the franchisee's gross subscriber revenues per year from cable television operations in the community (including all forms of consideration [paid to the operator], such as initial lump sum payments)." 47 C.F.R. $\$ 76.31(b)$ (1973). However, rates above three percent are permitted only in special cases. See Clarification IT 93, 101-06.

The language of the OTP bill may have unintentionally precluded the possibility of a licensing authority's charging an annual rate. The bill speaks in terms of the fee 
tion, however, prohibits the licensing authority from subjecting the cable operator, channel programmers, or cable subscribers to any special tax which is predicated solely on their use or operation of a cable system..$^{143}$ The effect of this provision should be to help insure that the cost of being a cable subscriber is not inflated with artificial costs and is consistent with a policy of expanding the industry.

\section{Judicial Authority}

The proposed Act has only two provisions authorizing access to the courts. Under section 501, aggrieved persons may challenge in state court any "act, practice, or omission" by a licensing authority or a cable operator on the grounds of noncompliance with the Act or state or local laws pursuant to the Act.144 Federal district courts are given jurisdiotion, without regard to citizenship or the amount in controversy, of any action which could have been brought under section 501.145 Although these provisions cover most parties whose right to sue might

being imposed "upon the issuance of certificates of compliance [by the $\mathrm{FCC}$ ] or issuance of licenses." Proposed Act $\S 401$ (c). If this language is interpreted to mean that the licensing authority can only clarge a lump sum amount, this provision is unwise because it will increase the amount of capital that an operator will need initially to set up a system. If this provision is unchanged, it would be better for the development of the cable industry to construe the "upon issuance" language only as a condition precedent with no implications for how the fees may be collected.

143. Proposed Act $\S 401$ (c).

144. Id. \$ 501:

Any person adversely affected or aggrieved by any act, practice, or omission of a cable licensing authority or cable operator may bring an action in a court of competent jurisdiction to challenge such act, practice, or omission, on the ground that it does not comply with the provisions of this Act or the provisions of a statute, ordinance or law of a State, or political subdivision thereof, intended to inpleinent or apply the provisions of this Act.

It is noteworthy that by its terms this proposed statute would not provide an action based upon noncompliance with a federal or state rule pursuant to the proposed Act. This anomaly should be cured by clianging the bill to read "or the provisions of a statute, ordinance, law, rule, regulation, or other requirenent of the United States or any agency thereof, or of a State, or agency or political subdivision thereof, intended ...." The most important aspect of this change would be that it would allow subscribers or others to sue the cable operator if he did not comply with FCC rules. At the state level, this change would be useful if the state's general administrative law did not permit suit because of violation of the licensing authority's rules.

145. Id. $\S 502$. A licensing authority will be a governmental entity. See note 133 supra. Therefore, it is possible that a defense to a suit under the proposed Act might be based upon sovereign immunity or the eleventh amendment. Congress has the power to remove a state's sovereign immunity. Comment, Implied Waiver of a State's Eleventh Amendment Immunity, 1974 DUKE L.J. 925, 940 n.82. Thus, the state court suit of section 501 is clearly free from objections based upon such immunity. The validity of the federal court suit provision is a far more coinplex problem. There is controversy as to the power of Congress to renove a state's eleventh amendment immunity. See id. at 939-54. 
otherwise be in doubt, ${ }^{146}$ they are significantly weakened by the lack of a damage remedy: the limitation of suits to challenges of acts, practices, and omissions seems to speak in terms of injunctive rehief. Possible abuses by cable operators (for example, disclosing private information about subscribers) would seein to be particularly remediable through monetary awards. To avoid any question as to the availability of such a remedy, the bill should clearly authorize both state and federal courts to provide whatever relief is appropriate. A further problem arises from the fact that only rarely would an abuse against an individual subscriber call for a large damage award. The lack of a jurisdictional amount for federal court suits is one appropriate way to deal with this problem; however, to reduce the expense of bringing suits, the statute should expressly provide for a class action by similarly aggrieved persons. This remedy would be an effective response to large-scale abuses affecting many subscribers. The expenses of such a class action could be further reduced by allowing notice to be given over the cable system. ${ }^{147}$

\section{CONCLUSION}

The proposed Cable Commumications Act is welcome as an attempt to establish uniform statutory regulation of cable TV. The bill would incorporate several features which are clearly desirable in terms of national policy. Notable among these are the broad prohibition of content controls for originated programs, the choice of ownership restrictions, the disallowance of a dedicated channels requirement, and the rules concerning subscriber and franchise fees. Unfortunately, the bill would also commit the nation to unwise policies in several areas. Too much power would be granted to the FCC to restrict the retrans-

146. The licensing authority would not qualify as a section 501 "person," see Proposed Act $\$ 105(\mathrm{~g})$ ("person" defined as "individual, partnership, association, joint stock company, trust, or corporation"), and therefore would not have the right of action given by section 501 . The only party likely to be sued by a hicensing authority is a cable operator, the terms of whose license would certainly include amenability to suit in state court. A cable operator's suit against subscribers (for example, on an overdue bill), channel lessees (for example, to enforce a leasing contract), and other parties would fall within the state courts' jurisdiction over contracts, torts, and other traditional subject areas.

147. Costs of notification unust be borne by the plaintiffs. Eisen v. Carlisle \& Jacquelin, 417 U.S. 156, 178 (1974). In that case, the cost of mailing notice originally would have been $\$ 225,000$, or $\$ 315,000$ by the time the Supreme Court decided the case. Id. at 167 \& n.7. Eisen, however, involved a class of six milhon members, id. at 166; suits against cable operators are unlikely to involve such large classes, since the largest systems currently have less than one hundred thousand subscribers. See Television FACTBOOK 70-a. 
mission of broadcast stations, thus making it possible for the FCC to serve broadcasters at the expense of the national interest in developing cable TV. The requirement that cable licensing authorities exercise exclusive control over cable in their jurisdictions is an unnecessary restriction upon the states. Furthermore, the provisions guaranteemg subscribers' privacy should be expanded to protect against imvasion by the government and to provide for sanctions. Finally, a class action against cable system operators should be allowed in the federal courts, with no jurisdictional amount and with notice to be given on the cable system. The bill has much to recommend it, but there is clearly a need for improvement; these changes should be made before the bill is enacted, or, ideally, even before it is sent to Congress. 